\title{
Mechanism of Pancreatic Islet Number Improvement on Hyperglycemic Wistar Rats (Rattus norvegicus) After Golden Sea Cucumber (Stichopus hermanii) Extract Administration
}

\author{
Riami, Exousia Kirana Chandra, Marisa Ummil Firdaus
}

\begin{abstract}
Diabetes mellitus constitutes a metabolic disorder indicated by a decrease in insulin secretion, insulin insensitivity, or a combination of both. Golden sea cucumber (Stichopus hermanii) is a natural resource of Indonesian waters with benefit for reducing blood sugar levels. This research aimed to determine the anti-hyperglycemic mechanism of golden sea cucumber.This study used a experimental laboratory research with Post-test Only Control Group. The sample of this study consisted of 25 male rats aged 60-70 days, divided into 5 groups: $K(-), K(+), P 1, P 2$, and $P 3$ randomly. Rats from $K(+), P 1, P 2$, and $P 3$ groups were injected with streptozotocin (STZ) with a dose of $50 \mathrm{mg} / \mathrm{kg} \mathrm{BW}$. Treatment was administered for 21 days. K(-) and $K(+)$ groups were fed normally while P1, $P 2$ and $P 3$ groups were given golden sea cucumber $80 \%$ ethanol extract with a dose of $4,25 \mathrm{mg} / \mathrm{kgBW} / \mathrm{day}, 8,50 \mathrm{mg} / \mathrm{kgBW} /$ day and $12,75 \mathrm{mg} / \mathrm{kgBW} / \mathrm{day}$ respectively. On the $22^{\text {nd }}$ day, fasting blood sugar level was measured and the number of pancreatic islet was counted with histopathological examination. The administration of golden sea cucumber (Stichopus hermanii) extract on rats with hyperglycemia does not reduce blood sugar level, but the extract administration increases the number of pancreatic islet. Golden sea cucumber (Stichopus hermanni) extract may improve the number of pancreatic islet and prevent the progressive damage of pancreatic islet.
\end{abstract}

Keywords: hyperglycemia, pancreatic islet, Stichopus hermanni

\section{INTRODUCTION}

Diabetes mellitus is a metabolic disorder characterized by hyperglycemic condition caused by a decrease in insulin production or ineffective use of insulin. Diabetes mellitus has become a global epidemic. For the past decades, the number and prevalence of diabetes mellitus continues to increase.

As the increasing number of global incidence, diabetes mellitus will potentially become the main cause of morbidity

Revised Manuscript Received on January 2, 2020.

* Correspondence Author

Riami*, Departement of Anatomy, Medical Faculty, Universitas Hang Tuah Surabaya, Indonesia. Email : riami@hangtuah.ac.id

Exousia Kirana Chandra, Study Program of Doctor, Medical Faculty, Universitas Hang Tuah Surabaya, Indonesia. Email: chandraexousia@yahoo.com

Marisa Ummil Firdaus, Study Program of Doctor, Medical Faculty, Universitas Hang Tuah Surabaya, Indonesia. Email: ummifirdausmarisa@gmail.com and mortality in the future (Powers, 2015). Chronic hyperglycemia and metabolic dysregulation in diabetes mellitus can cause secondary pathophysiological changes and damages to various organ systems, such as cardiovascular, nervous system, kidney, and eyes (American Diabetes Association, 2013).

Insulin is a hormone that maintain glucose homeostasis in the body. Insulin is produced by beta cells in pancreatic islets and stimulated by an increase in blood glucose concentration (Elayat, 1995). $70 \%$ of pancreatic islet mass consist on beta cells. Insulin deficiency and resistance causes hyperglycemia because the body can't utilize blood glucose. This insulin deficiency can be caused by beta cell destruction (Powers, 2015). Beta cell destruction is shown by a decrease of the number, size, and density of the pancreatic islet (Vessal et al., 2013). This beta cell destruction is closely related to free radical build up and inflammation process.

A good control of diabetes mellitus can be achieved by combination of factors, such as consistent use of drugs, insulin therapy, diet planningoi, and physical exercise (Ruslianti, 2008). Unfortunately, this continuous use of antidiabetic drugs has a couple of side effects such as an increase of body weight, diarrhea, bloated stomach, and kidney dysfunction. Thus an alternative complimentary drugs that contains antioxidant is needed to reduce this oxidative stress.

Indonesia is the largest archipelago, with an ocean area of 5,8 million $\mathrm{km}^{2}$. This makes Indonesia has a great potency for marine biota, one of which is sea cucumber. For the past 200 years, Indonesia has become one of the high quality sea cucumber producing country (DKP, 2006). The use of sea cucumber as a nutritious food sources which as a beneficial health properties has since long started. Currently some species of sea cucumber has been proved for having a high bioactive components that are beneficial for health, where one of them are golden sea cucumber (Stichopus hermanni) Golden sea cucumber (Stichopus hermanni) contains high protein level (44-55\%) and numerous bioactive component such as flavonoid and saponin. Golden sea cucumber (Stichopus hermanni) is well known for it's high antioxidant properties, such as saponin, and also for it's capability to trigger cell regeneration (Wang, 2017).

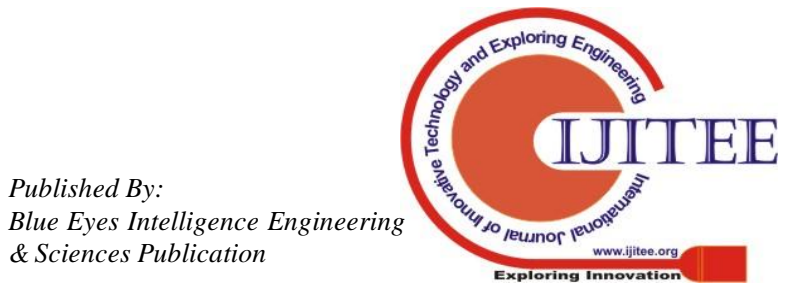




\section{MATERIALS AND METHODS}

\section{A. Research Design}

The research is an experimental laboratory study with Post-test only Control Group Design conducted in the biochemistry section of the Veterinary Faculty of Medicine, Airlangga University. The experimental animal that is used was adult male Wistar strain rats ( $R$. norvegicus domesticus) aged 60-70 days with a BM of 150-200 grams with a good health. Experimental animals are given standard food and drink ad libitum. The minimum sample size used are five rats for each treatment group. The total sample size is 25 rats. To decided the number of samples or experimental units used in this study, the large sample formula from Federer.

There are 2 sample groups in this research, which are control groups and treatment groups. Control group, which are not given treatment, are divided into positive control group and negative control group. Treatment groups, are a group of rats that are given treatment, which are divided into 3 treatment groups with different extract doses.

All rats will be acclimatized for 7 days, where each rats will be divided into each group sample randomly. During this research 5 groups of male Wistar rats (Rattus norvegicus): $\mathrm{K}(-)$ : a group of male Wistar rats not made diabetic with STZ; K (+): male Wistar rats (Rattus norvegicus) made diabetic induced with STZ; P1: male Wistar rats (Rattus norvegicus) made diabetic with STZ and administered golden sea cucumber extract with a dose of 4.25 $\mathrm{mg} / \mathrm{kgBW} / \mathrm{day} ; \mathrm{P} 2$ : male Wistar rats (Rattus norvegicus) made diabetic with STZ and administered golden sea cucumber extract with a dose of $8.25 \mathrm{mg} / \mathrm{kgBW} / \mathrm{day}$; P3: male Wistar rats (Rattus norvegicus) made diabetic with STZ and administered golden sea cucumber extract with a dose of $12.75 \mathrm{mg} / \mathrm{kgBW} /$ day. After being given treatment, blood extraction from the experimental animals and collection of the pancreas are conducted. The histopathological sediment are then made which will then be analyzed for the number of Pancreatic Langerhans Islets on the 5 groups.

All materials and methods that have been used in the work must be stated clearly and subtitles should be used when necessary.

\section{B. Golden Sea Cucumber (Stichopus hermanii) Extraction}

Golden sea cucumber extract (Stichopus hermanni) are extracts made from golden sea cucumber from the waters of Sumenep, Madura. These extracts are acquired through an extraction process of using ethanol (maceration method). Based on the study of Safitri et al. (2019), the extraction process is made through this process in which are: fresh Stichopus hermanni with a total mass of $9 \mathrm{~kg}$, are cleansed then chopped into small pieces with a length of 3-10, then dried in the oven for $50^{\circ} \mathrm{C}$ until they are completely dried. Dried Sticophus hermanni would then be grinded using a blender and are made into a powdery form which would weight around $1,3 \mathrm{~kg}$. Powdery Stichopus hermanni will then be macerated then mixed for 8 hours continuously then soaked in $80 \%$ ethanol for 24 hours, after 24 hours $80 \%$

ethanol would then be collected and pulp Stichopus hermanii would be macerated once again with $80 \%$ ethanol same as previously (with the total ethanol solution used is 5,5 liter). The acquired ethanol $80 \%$ would be evaporated with water with a temperature $50{ }^{\circ} \mathrm{C}$ until the ethanol evaporates and 242,5 grams of Sticophus hermanii are acquired.

\section{Treatment Group}

A total of 25 male rats aged 60-70 days with the BW of 150-200 gr are randomly divided into four groups (K-, K+, P1, P2, P3). Male Wistar rats for $\mathrm{K}(+), \mathrm{P} 1, \mathrm{P} 2$, and P3 with the criteria above were injected with streptozotocin with a dose of $50 \mathrm{mg} / \mathrm{kgBW}$ to create diabetic male Wistar rats. Diabetic male Wistar rats are indicated by fasting blood sugar (FBS) Level measured after 48 hours after injection while the level of FBS is above $14 \mathrm{mmol} / \mathrm{L}$ or $252 \mathrm{mg} / \mathrm{Dl}$ and accompanied by polyphagia, polydipsia, polyuria, and weight loss. For treatment, the K (-) or normal control group was treaded with normal saline, the $\mathrm{K}(+)$ or $\mathrm{DM}$ control group was treated with normal saline, the P1, P2, P3 or DM group was administered with golden sea cucumber (Stichopus hermanni) extract with a dose of $4,25 \mathrm{mg} / \mathrm{kgBW}, 8,50$ $\mathrm{mg} / \mathrm{kgBW}$, and $12,75 \mathrm{mg} / \mathrm{kgBW}$.

\section{FBS Measurement}

The blood glucose is measured using a glucometer. The glucometer is adjusted and settled according to the glucose stick code used, and then the blood samples that are collected from the tail are dripped onto the stick connected to the glucometer.

\section{E. Pancreatic Slide Preparation}

The rats are euthanized intramuscularly by ketamine and the dissection of rats are performed to collect the pancreatic organ. The pancreatic organ, embedded in a paraffin block, is fixed in the microtome block holder and arranged parallel to the microtome blade. The pancreas organ is then sliced to a size of $5 \mu \mathrm{m}$. The slices are collected by brush and put on the surface of room temperature water to unfold the crease that might occur during the preparation. The slices are then transferred with a brush into warm water $\left(38-40{ }^{0} \mathrm{C}\right)$ to straighten any possible wrinkles. A perfectly stretched slice is taken with a glass slide. The glass sliders placed on a 38-40 ${ }^{0} \mathrm{C}$ hot plate until dry, and then, the glass slides are stored in an incubator at $38-40{ }^{\circ} \mathrm{C}$ for 24 hours.

\section{DATA ANALYSIS}

All data from FBS level and the number of pancreatic islet are tested. Homogeneous data are tested using Brown-Forsy test with a significance of $5 \%$, then the Gomes-Howell test is carried out to find out which groups were different.

\section{RESULTS AND DISCUSSION}

\section{A. FBS Level}

Based on the normality test of the FBS Level, all the groups $(\mathrm{K}(-), \mathrm{K}(+), \mathrm{P} 1, \mathrm{P} 2$, and $\mathrm{P} 3)$ has a value of $>0,05$ which means that all the data are distributed normally. 
The next test to be conducted is the homogenity Levene's test. Results from the Levene's test, shows that the data are all homogenous. The next one to be analyzed is the FBS Level, results of FBS Level using Kruskal-Wallis test does not show a significant difference between all the groups $\mathrm{K}(-), \mathrm{K}(+), \mathrm{P} 1$, $\mathrm{P} 2$, and P3.

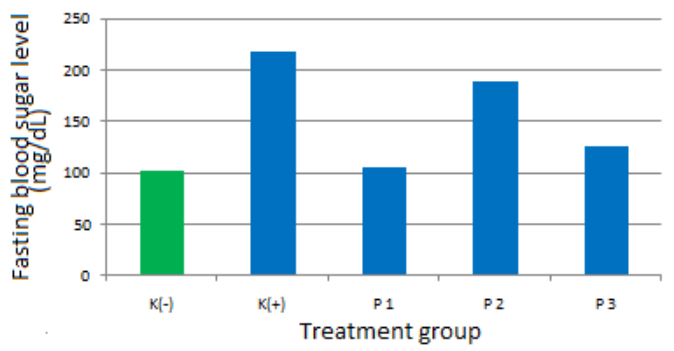

Fig 1. The fasting blood sugar level in each group is not significant in compared to the $K(+)$

\section{B. The Number of Pancreatic Islet}

Figure 2 Shows the number of pancreatic islet observation with Hematoxylin-Eosin histochemical staining. Negative control group (K-) has an average number of pancreatic islets Positive control group that is induced with STZ with a dose of $50 \mathrm{mg} / \mathrm{BW}$ has an average number of pancreatic islets with a total of 1,200 islets and a standard deviation of 0,283. First treatment group (P1) that is induced with STZ with a dose of $50 \mathrm{mg} / \mathrm{BW}$ and given $4,25 \mathrm{mg} / \mathrm{BW} /$ day golden sea cucumber extract has an average number of pancreatic islets with a total of 1,280 islets and a standard deviation of 0,228. Second treatment group (P2) that is induced with STZ with a dose of $50 \mathrm{mg} / \mathrm{BW}$ and given $8,5 \mathrm{mg} / \mathrm{BW} /$ day golden sea cucumber extract has an average number of pancreatic islets with a total of 1,560 islets and a standard deviation of 0,297. Third treatment group (P3) that is induced with STZ with a dose of $50 \mathrm{mg} / \mathrm{BW}$ and given $12,75 \mathrm{mg} / \mathrm{BW} /$ day golden sea cucumber extract has an average number of pancreatic islets with a total of 2,280 islets and a standard deviation of 0,335 .

From the data above, it is known that there are a decrease in the average numbers of pancreatic Langerhans islets in the experimental animal groups induced with STZ and that there are an increase in the average number of pancreatic Langerhans islets when compared to the positive control group. From the Shapiro-Wilk normality test, each group are distributed normally. Test results from the homogenity test from each group, negative control group (K-), positive control group $(\mathrm{K}+)$, first treatment group (P1), second treatment group (P2), and third treatment group (P3). Results from the normality test shows that the data is homogenous.

Therefore to analyze the data next, the parametric analysis test One-Way Anova is used. Results from the One-Way Anova test shows a significant value of $\mathrm{p}=0,001(\mathrm{p}$ $<0,05)$. From this result in can be concluded that there are a significant differences on the number of pancreatic Langerhans Islets between negative control group $(\mathrm{K}(-))$, positive control group $(\mathrm{K}(+))$, first treatment group (P1), second treatment group (P2), and third treatment group 3 (P3). To find the group that a significant difference amongst with a total of 3,440 islets and a standard deviation of 0,358 .

other groups, the Post-Hoc LSD test is conducted. Based on the results from the Post-Hoc LSD test, data acquired are: there are a significant difference between the $\mathrm{K}(-)$ and $\mathrm{K}(+)$, $\mathrm{K}(-)$ and P1, K (-) and P2, P1 and P3, P2 and P3, while there are no significant difference between the $\mathrm{K}(+)$ and $\mathrm{P} 1, \mathrm{~K}(-)$ and $\mathrm{P} 2, \mathrm{~K}(+)$ and $\mathrm{P} 3$.
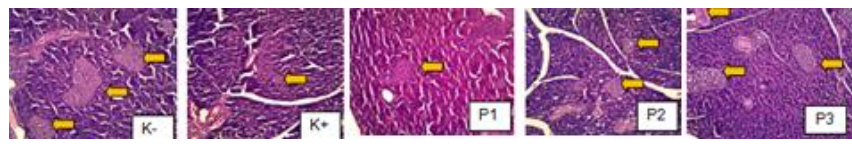

Fig 2. Rat pancreatic islet with Hematoxylin-Eosin histochemical staining and 400 magnification. The arrow shown the pancreatic islet

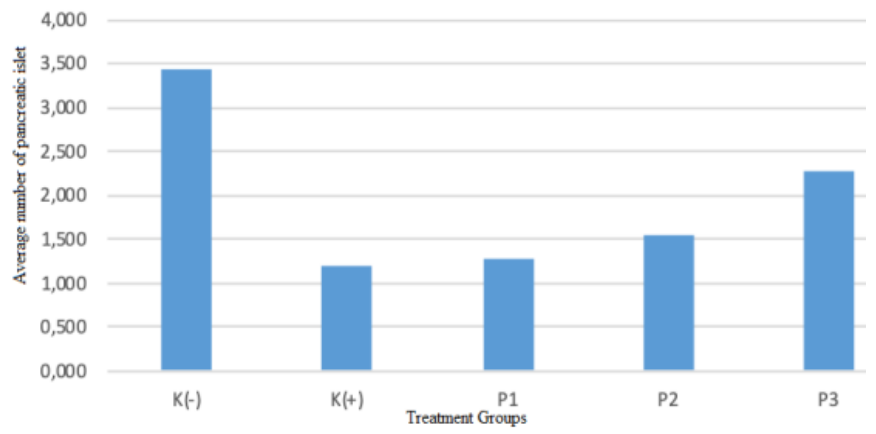

Fig 3. The number of pancreatic islet

The research method used is Post test Randomized Control Group Design. This research uses control groups and treatment groups, in which the control groups are further divided into negative and positive control group. The treatment groups consisted of 3 group with different extract dosages. After a period of acclimatization of 7 days, each rat are divided randomly into separate sample groups. In this research, 5 groups of white male wistar rats (Rattus norvegicus) are used, the negative control group $(\mathrm{P}(-))$ : group of rats which are given standard diet. The positive control group $(\mathrm{P}(+))$ is made diabetic induced by STZ. The first treatment group (P1) is induced by STZ and given golden sea cucumber (Stichopus hermanni) extract with a dose of $4.25 \mathrm{mg} / \mathrm{KgBW} /$ day. The second treatment group (P2) is induced by STZ and given golden sea cucumber (Stichopus hermanni) extract with a dose of $8.5 \mathrm{mg} / \mathrm{KgBW} /$ day. The third treatment group (P3) is induced by STZ and given golden sea cucumber (Stichopus hermanni) extract with a dose of $12.75 \mathrm{mg} / \mathrm{KgBW} /$ day. After exposure to treatment, the pancreas of the white male Wistar rats (Rattus norvegicus) are collected and made into histopathology samples. Analysis of pancreatic Langerhans islets count on 5 sample groups are then conducted. Based on the statistical test run upon the administration of golden sea cucumber (Stichopus hermanni), it is shown that there are no decrease in FBS level albeit a clinically decreased FBS level on P1, P2, and P3. In P1, the administration of golden sea cucumber (Stichopus hermanni) with a dose of $4.25 \mathrm{mg} / \mathrm{KgBW} /$ day proves to be more effective at decreasing FBS level in compared to $\mathrm{P} 2$ and $\mathrm{P} 3$.

।

Published By: 


\section{Mechanism of Pancreatic Islet Number Improvement on Hyperglycemic Wistar Rats (Rattus norvegicus) After Golden Sea Cucumber (Stichopus hermanii) Extract Administration}

In this research, the average number of pancreatic islet of Langerhans in the negative control group (K-) is 3,44, meanwhile, the average number of pancreatic islet of Langerhans in the positive control group $(\mathrm{K}+)$ is 1,2 . This shows that induction of STZ in trial animals leads to the destruction and decrease of pancreatic beta-cells number. In hyperglycemic condition, a decrease of pancreatic beta cells up to $50 \%$ from the normal takes place (Oche et al., 2014). The decrease of pancreatic beta cells causes the decrease in number, size, and or density of Langerhans islets. This is parallel to the study conducted by Vessal et al. 2003, in which it is found that there is a decrease of pancreatic Langerhans islets per unit area on trial animals induced by STZ.

STZ forms highly reactive free radical that damages cells membranes, proteins, and DNA, contributing to the damage of pancreatic beta cells. The increase of ROS (reactive oxygen species) in pancreatic beta cells causes damage and necrosis to pancreatic beta cells, thus decreasing the pancreatic beta cells numbers. As a result, insulin synthesis and secretion which leads to the inhibition of insulin synthesis and secretion causes hyperglycemic condition. The selectivity of streptozotocin towards pancreatic beta cells is caused by the entry of streptozotocin through glucose-transporter-2 (GLUT2). There are 2 main mechanisms of STZ in causing damage to pancreatic beta cells. Firstly, when STZ has entered the cells, it will increase guanylyl cyclase and cGMP thus increasing the production of nitric oxide. Nitric oxide is one of the free radicals that causes cells damaging oxidative stress. Furthermore, the ATP dephosphorization of ATP will increase xanthine oxide substrate which produces hydrogen peroxide and hydroxyl radical. The combination of nitric oxide and various oxygen reactive molecule that is produced can cause DNA fragmentation (Szkudelski, 2001). Secondly, STZ can damage DNA through a direct process of DNA methylation in which it forms carbonium ion $(\mathrm{CH} 3+)$. This will lead to the activation of poly-ADP-ribose synthetase (PARP) enzyme. The activation of PARP itself is in actuality an effort of the body to fix the damaged DNA. This process is then proceeded by the depletion of NAD+ and the decrease of cell's ATP reservoir, thus contributing to the necrosis of pancreas (Eleazu, 2013).

In this research, there is a significant difference in the number of Langerhans islets in group P3 as compared to the $\mathrm{K}+$ group. This is parallel to the findings in the study conducted by Vessal et al. 2004, in which the administration of Teucrium polium extract with antioxidant activity attributed to flavonoid, saponin, and alkaloid contained in the extract for 10 days increases the number of Langerhans islets in diabetic Sprague-Dawley rats induced by streptozotocin. Statistically speaking, there are no significant difference between the number of Langerhans islets on P1 group in compare to the $\mathrm{K}(+)$ group, and between the P2 and $\mathrm{K}(+)$ group. The average number of Langerhans islets in group P1 and P2 is higher than the $\mathrm{K}(+)$ group. Thus, the administration of golden sea cucumber (Stichopus hermanni) extract with a dose of $4.25 \mathrm{mg} / \mathrm{KgBW} /$ day on P1 group and a dose of $8.5 \mathrm{mg} / \mathrm{KgBW} /$ day in $\mathrm{P} 2$ group is proven to have increased the number of pancreatic Langerhans islets in compare to the positive control group $(\mathrm{K}+)$ induced by STZ albeit statistically insignificant.

Golden sea cucumber (Stichopus hermanni) extract is rich in antioxidant such as flavonoid and saponin. Saponin works as antioxidant by disintegrating free radical DPPH, and prevent lipid peroxidation and the formation of AGE (Nafiu and Ashafa, 2017). Flavonoid inhibits free radical activity like superoxide anion radical and hydroxyl free radical (Pietta, 2000). Therefore, flavonoid and saponin work as antioxidant that oppresses the number of free radical in the body thus decreasing the damage of pancreatic beta cells and the occurring insulin resistance. Moreover, antioxidant like saponin and flavonoid increases pancreatic beta cells regeneration through neogenesis and beta cells proliferation process. The administration of antioxidant containing supplements can increase the rate of proliferation of pancreatic beta cells, which shows the negative effect of oxidative stress on the regeneration of pancreatic beta cells (Wang, 2017). The increase in the number of pancreatic beta cells will then increase the number of pancreatic Langerhans islets.

Based on this discussion, it can be concluded that the most effective dosage of golden sea cucumber (Stichopus hermanni) extract that can significantly increase the number of Langerhans islets of diabetic male Wistar rats induced by $\mathrm{STZ}$ is $12.75 \mathrm{mg} / \mathrm{KgBW} /$ day that is given for 21 days.

\section{CONCLUSION}

The administration of golden sea cucumber (Stichopus hermanni) in Wistar rats induced with Streptozotocin can increase the number of Langerhans islets even though an improvement of the hyperglycemic condition is not yet attainable.

\section{ACKNOWLEDGEMENT}

Thank you to Hang Tuah University Faculty of Medicine and Embryology Laboratory of Universitas Airlangga Surabaya Faculty of Veterinary that has helped in the realization of this research.

\section{REFERENCES}

1. Bordbar, S., Anwar, F. and Saari, N. (2011) 'High-Value Components and Bioactives from Sea Cucumbers for Functional Foods - A Review', pp. 1761-1805. doi: 10.3390/md9101761.

2. Grotewold, E. (2006) The Science of Flavonoids.

3. Hostettmann, K. (1995) 'Saponins : Properties, Applications', (February). doi: 10.1080/10408390600698197.

4. Indraswary, R. (2011) Effect of Topical Extract (Foeniculum vulgare Mill) in Epithelization in Healing Gingival Wound of Labial Sprague Dwaley In Vivo. (Efek Konsentrasi Ekstrak Buah Adas (Foeniculum vulgare Mill) Topikal Pada Epitelisasi Penyembuhan Luka Gingiva Labial Tikus Sprague Dwaley In Vivo)

5. Lenny, S. and Ssi, M. (2006) 'Flavonoids, Phenylpropanoids, and Alkaloids', USU Reporsity, pp. 1-25. Available at: http://library.usu.ac.id/download/fmipa/06003489.pdf. (Senyawa Flavonoida, Fenilpropanoida, dan Alkaloida).

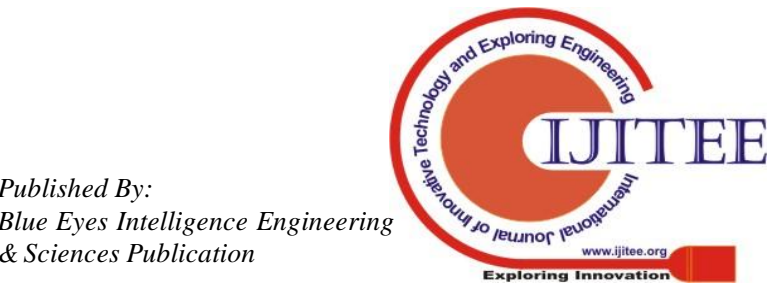


6. Nafiu, M. O. and Ashafa, T. A. O. (2017) 'Antioxidant and Inhibitory Effects of Saponin Extracts from Dianthus basuticus Burtt Davy on Key Enzymes Implicated in Type 2 Diabetes In vitro'.

7. Oche, O. et al. (2014) 'Pancreatic islet regeneration and some liver biochemical parameters of leaf extracts of Vitex doniana in normal and streptozotocin-induced diabetic albino rats', Asian Pacific Journal of Tropical Biomedicine, 4(2), pp. 124-130. doi: 10.1016/S2221-1691(14)60220-3.

8. Pearce, I. A. et al. (2000) 'Stabilisation of diabetic retinopathy following simultaneous pancreas and kidney transplant', British Journal of Ophthalmology, 84(7), pp. 736-740. doi: 10.1136/bjo.84.7.736.

9. Pechhold, K. et al. (2009) 'Blood Glucose Levels Regulate Pancreatic b -Cell Proliferation during Experimentally-Induced and Spontaneous Autoimmune Diabetes in Mice', 4(3). doi: 10.1371/journal.pone.0004827.

10. Pietta, P.-G. (2000) 'Reviews Flavonoids as Antioxidants', J. Nat. Prod., 63, pp. 1035-1042. doi: 10.1021/np9904509.

11. Pitocco, D. et al. (2013) 'Oxidative stress in diabetes: Implications for vascular and other complications', International Journal of Molecular Sciences, 14(11), pp. 21525-21550. doi: 10.3390/ijms141121525.

12. Pringgenies, D., Rudiyanti, S. and Yudiati, E. (2018) 'Exploration of Sea Cucumbers Stichopus hermanii from Karimunjawa Islands as Production of Marine Biological Resources', IOP Conference Series: Earth and Environmental Science, 116(1). doi: 10.1088/1755-1315/116/1/012039.

13. Safitri, I. et al. (2019) 'Effect of Sticophus hermanii extract on fasting blood glucose and skeletal muscle glut 4 on type 2 diabetes mellitus rats model', IOP Conference Series: Earth and Environmental Science, 217(1). doi: 10.1088/1755-1315/217/1/012025.

14. Vessal, M., Zal, F. and Vasei, M. (2003) 'effects of Teucrium polium on oral glucose tolerance test, regeneration of pancreatic islets and activity of hepatic glucokinase in diabetic rats', Archives of Iranian Medecine, 6(1), pp. $35-39$.

15. Wang, J. and Wang, H. (2017) 'Oxidative stress in pancreatic beta cell regeneration', Oxidative Medicine and Cellular Longevity, 2017. doi: $10.1155 / 2017 / 1930261$.

16. Wu, K. K. and Huan, Y. (2008) 'Streptozotocin-Induced Diabetic Models in Mice and Rats', (March), pp. 1-14. doi: 10.1002/0471141755.ph0547s40

\section{AUTHORS PROFILE}

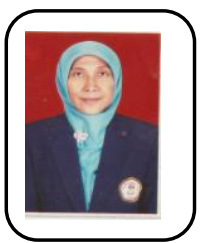

\section{First Author}

Dr. Riami, dr., MKes Lecturer of Anatomy at Faculty of Medicine, Hang Tuah University. Educational details: General practitioner at the Faculty of Medicine Hang Tuah University Surabaya (2000); Masters of Medicine at the Faculty of Medicine Airlangga University Surabaya (2005); Doctoral Program at the Faculty of Medicine Airlangga University Surabaya (2018). Publication: The Effect of Soy Milk Giving on Renal Histopathology in Rats induced by high-dose paracetamo (Pengaruh Pemberian susu kedelai terhadap gambaran histopatologi ginjal tikus yang diinduksi parasetamol dosis tinggi ). (2011; Hang Tuah Medical Journal. Vol.09; No.01; pp. 75-79); The effect of Olive oil (Olive oil) as anti-inflammatory in white rats (Rattus norvegicus) male who are given a high-fat diet (Efek minyak Zaitun (Olive oil) sebagai anti radang pada tikus putih (Rattus norvegicus) jantan yang diberi diet tinggi lemak). (2012; .Hang Tuah Medical Journal; Vol.10; No.01; pp. 50-52) ;The effect of red betel leaves (Piper crocatum Ruiz and Pav.) on blood sugar and insulin expression levels in rat (Rattus norvegicus domesticus) models of diabetes mellitus (2019; Drug Invention Today. Vol. 11; No.03; pp553-557):

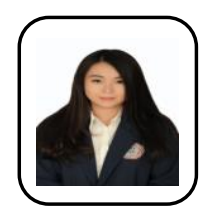

Second Author:

Exousia Kirana Chandra

Study Program of Doctor, Medical Faculty, Universitas

Hang Tuah Surabaya, Indonesia

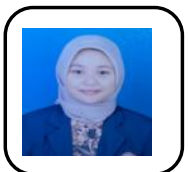

Third Author

Marisa Ummil Firdaus

Study Program of Doctor, Medical Faculty, Universitas

Hang Tuah Surabaya, Indonesia 